A. A. Gde Satia Utama dkk: Automatic Management Inventory System (AMIS) ...

\title{
AUTOMATIC MANAGEMENT INVENTORY SYSTEM (AMIS): EFEKTIVITAS PENGAWASAN DAN PENGELOLAAN PERSEDIAAN TERINTEGRASI
}

\author{
A.A Gde Satia Utama \\ Fakultas Ekonomi Dan Bisnis, Universitas Airlangga \\ gde.agung@feb.unair.ac.id \\ Erdiya Vega Restiyantingrum \\ Fakultas Ekonomi Dan Bisnis, Universitas Airlangga \\ Arina Manasika \\ Fakultas Ekonomi Dan Bisnis, Universitas Airlangga \\ Eky Asroatul Laila \\ Fakultas Ekonomi Dan Bisnis, Universitas Airlangga \\ I Gede Oka Mahendra Sidhi Pramesti \\ Fakultas Ekonomi Dan Bisnis, Universitas Airlangga
}

\begin{abstract}
ABSTRAK
Tujuan penelitian ini adalah untuk memberikan informasi kinerja aplikasi AMIS yang dapat dipergunakan secara tepat dan pasti untuk mengetahui berapa total persediaan yang masih ada digudang atau persediaan yang menjadi safety stock dan berapa persediaan yang harus dilakukan penambahan atau pembeliaan. Maka dari itu, aplikasi AMIS dirancang untuk meminimalisir adanya fraud dan error dalam management persediaan suatu perusahaan yang secara otomatis yang terhubung dengan Manajer yang terkait dengan persediaan dan Direktur yang melakukan fungsi pengawasan. Cara pengoperasian AMIS menggunakan aplikasi yang terkomputerisasi yang ada pada gudang dan terhubung keseluruh komputer pada bagian lain yang terkait dengan persediaan. Untuk mengetahui total dan jenis persediaan di gudang secara akurat, AMIS dipermudah dengan suatu alat yang disebut dengan Screening Laser.Analisa data dalam penelitian menggunakan data kualitatif dengan sumber data primer dan skunder. Cara pengambilan sampel menggunakan random sampling. Ketika suatu persediaan sudah kurang dari batas minimal untuk penyimpanan digudang dan diperlukan adanya
\end{abstract}


pembelian, maka alat tersebut akan memberikan isyarat ke bagian pembelian. Setelah bagian pembelian melakukan order barang dan otorisasi oleh manajer maka alat tersebut akan menghentikan isyaratnya dan menginput jumlah masukan persediaan yang sudah datang. Sehingga aplikasi ini dinilai sangat efektif untuk mengetahui EOQ, safety stock, reorder point. Selain itu, memberi kemudahaan dalam pembutan laporan, proses otorisasi dan pengambilan keputusan.

\section{Key Word: AMIS, Internal control, Persediaan, Sistem}

\section{PENDAHULUAN}

Pada perusahaan dagang maupun manufaktur, prosedur persediaan barang sangat penting dan sebagai salah satu roda penggerak dalam kelangsungan hidup perusahaan. Pengendalian internal memiliki pengaruh sangat besar atas laporan barang maupun keuangan. Pengelolaan persediaan merupakan masalah yang penting bagi perusahan, karena mempunyai efek langsung terhadap keuntungan perusahaan, serta memperbesar kerugian karena kerusakan, turunnya kualitas ataupun keusangan. Menurut (Murtanto, 2013)dalam bukunya yang berjudul Sistem Pengendalian Internal mendefinisikan 3 tujuan efektifitas pengendalian internal persediaan barang adalah : (1) Operasi yang efektif dan efisien (2) Keandalan Informasi Keuangan (3) Kepatuhan terhadap hukum dan peraturan yang berlaku.

Pada umumnya perhitungan fisik persediaan yang ada di gudang dilakukan dengan cara manual atau yang biasa kita sebut dengan stock 
A. A. Gde Satia Utama dkk: Automatic Management Inventory System (AMIS) ...

opname. Tujuan dilakukannya stock opname adalah untuk mengetahui keakuratan catatan pembukuan yang merupakan salah satu fungsi sistem pengendalian intern suatu perusahaan. Keakuratan catatn pembukuan tersebut merupakan kesesuaian antara catatan dengan fisik yang ada. Jika terjadi selisih diantaranya, maka bisa ditelusuri lebih lanjut apa penyebabnya, juga dapat diprediksi adanya potensi fraud dan error.Stock opname memiliki 3 proses penting yakni tahap awal (dilakukan jauh-jauh hari sebelum stock opname), tahap persiapan (dilakukan h-1 stock opname), dan tahap stock opname. Selain itu, juga dibutuhkan banyak tenaga kerja untuk bagian perhitungan dan input barang yang pastinya membutuhkan anggaran yang lebih untuk hal tersebut. Sedangkan biaya tenaga kerja terus meningkat. Penulis memiliki inisiatif untuk mendesign suatu software yang dinilai mampu untuk menggatikan sistem stock opname sehingga menekan biaya yang dikeluarkan perusahaan dan mampu meminimalisir adanya fraud dan error yang disebabkan oleh tenaga kerja. Selain itu mempermudah pembuatan beberapa dokumen dan mempermudah manajer dalam pembuatan keputusan, juga otorisasi. Berdasarkan latar belakang tersebut maka permasalahan dalam artikel ini adalah implementasi dan sistem kerja AMIS pada pengawasan dan pengelolaan persediaan terintegrasi. 


\section{TINJAUAN PUSTAKA}

\section{Penelitian Terdahulu}

Beberapa penelituan terdahulu pernah dilakukan seperti pada Amelia dan Joni Devitra (2018) yang berjudul "Analisis dan Perancangan Sistem Informasi Manajemen Persediaan Barang pada Advan Service Center Jambi ". Tujuan dari penelitian ini adalah untuk merancang suatu sistem informasi manajemen persediaan barang di Advan Service Center Jambi yang dapat mengontrol dan mengolah data barang. Hasil penelitian yang dilakukan oleh peneliti menunjukkan bahwa sistem informasi manajemen persediaan barang yang ada di Advan Service Center Jambi masih secara manual dan belum menggunakan database sehingga data-data tidak tersimpan dengan baik. Peneliti juga menggunakan analisis kebutuhan sistem diterjemahkan dengan alat bantu UML (Unified Modelling Language) dalam bentuk usacase diagram untuk menggarmbarkan berbagai fungsi dari sistem class diagram untuk mengetahui class yang terbentuk serta hubungan antar class tersebut. Actifity Diagram menggambarkan alur aktifitas dalam sistem. Peneliti juga menghasilkan sebuah prototype sistem informasi manajemen persediaan barang yang dapat diimplementasikan sesuai dengan kebutuhan yang ada, terutama dalam pengolahan data persediaan barang yang dikelola oleh admin 
A. A. Gde Satia Utama dkk: Automatic Management Inventory System (AMIS) ...

Advan Service Center Jambi yang menampilakan beberapa laporan, yaitu laporan persediaan barang, laporan penerimaan barang, laporan pemakaian barang dan laporan pemesanan barang.

Yosan, et al (2014) yang melakukan penelitian yang berjudul "Implementation of Inventory Management Systm (IMS) Case Study on XYZ Online Store Business Unit". Tujuan dari penelitian tersebut adalah untuk mengetahui toko tersebut berani untuk menjual produk mereka kepada target konsumen mereka. Hasil pembahsan penelitian tersebut peneliti memiliki hasil dari perhitungan yang telah dilakukan diteukan ROP memiliki nilai 110 unit dan order quantity 19 kali dalam satu tahun. Perbaikan gudang harus segera dibutuhkan dan standarisasi dan alokasi penempatan gudang untuk stok barang. EOQ dengan nilai 22 unit perpesanan sebagai jawaban yang dibutuhkan untuk pesanan pada gudang untuk antisipasi gudang agar lebih baik.

\section{Pengendalian Persediaan}

Penelitian yang dilakukan mengarah pada pengendalian persediaan agar tidak terjadi kecurangan pada saat penyimpanan barang di gudang dan pada saat penentuan kuantitas barang yang harus dipesan. Menurut Atmadja, dkk (2013) pengendalian persediaan sangat penting dalam manajemen, khususnya pada manajemen produksi dan operasi. Persediaan yang 
berlebihan akan mengakibatkan pengeluaran biaya yang tinggi, sedangkan persediaan yang tidak cukup akan mengakibatkan terhambatnya suatu kegiatan operasional perusahaan. Pengendalian persediaan yang baik dengan menggunakan manajemen persediaan, manajemen persediaan yang baik adalah manajemen persediaan yang dapat menjaga keseimbangan antara investasi persediaan dengan tingkat pelayanan kepada konsumen. Jadi dalam penelitian ini melakukan pengendalian persediaan dengan menggunakan manajemen inventory dan juga dengan metode EOQ. Dalam pengendalian persediaan dalam penelitian ini mengendalikan persediaan yang ada di gudang untuk penyimpanan barang untuk dijual.

Menurut Michael Chandra Tuerah (2014:526) yang dikutip dari Herjanto (2008:238), Pengendalian persediaan adalah serangkaian kebijakan pengendalian untuk menentukan tingkat persediaan yang harus dijaga, kapan pesanan untuk menambah persediaan harus dilakukan dan berapa besar pesanan harus diadakan, jumlah atau tingkat persediaan yang dibutuhkan berbeda-beda untuk setiap perusahaan pabrik, tergantung dari volume produksinya, jenis perusahaan dan prosesnya.

\section{Manajemen Inventory}

Manajemen persediaan adalah salah satu bagian dalam manajemen operasional dan manajemen produksi. dalam situs ini yang dikutip dari 
A. A. Gde Satia Utama dkk: Automatic Management Inventory System (AMIS) ...

businessdictionary.com menyebutkan bahwa manajemen persediaan adalah kegiatan untuk menjaga jumlah optimum dari barang yang dimiliki. Berdasarkan pengertian di atas dapat ditarik kesimpulan bahwa dalam suatu proses bisnis harus ada pengontrolan dari pergerakan barangnya, yang juga memerlukan pengelolaan yang baik terhadap barang agar tidak terjadi kesalahan dalam penyimpanan barang dalam gudang. Dan dengan pengelolaan tersebut yang disebut dengan manajemen persediaan (Atmadja, dkk, 2013).

\section{EOQ (Economic Order Quantity)}

Untuk menerapkan pengelolaan persediaan yang baik atau manajemen persediaan yang baik, penelitian ini menggunakan salah satu metode, yaitu metode Economic Order Quantity. Menurut jurnal yang dikarang oleh Andini dan Slamet $(2016 ; 145)$ mengartikan EOQ yang mengutip dari Haming dan Mahfud $(2007 ; 10)$ EOQ adalah jumlah unit yang dipesan pada biaya yang paling murah (ekonomis) atau optimal. Sedangkan menurut Slamet $(2007 ; 70)$ sendiri EOQ adalah kuantitas bahan baku dan suku cadangannya yang dapat diperoleh melalui pembelian dengan mengeluarkan biaya minimal tetapi tidak berakibat pada kekurangan dan kelebihan bahan baku dan suku cadangannya. 
Dalam penelitian ini EOQ digunakan untuk menentukan unit ideal pada saat kuantitas barang berapa perusahaan harus memasok barang lagi. Penentuan pemesanan barang tersebut agar barang yang ada dalam gudang perusahaan tidak mengalami kebusukan atau usang. Jadi dalam pengendalian barang yang ada di gudang atau manajemen persediaan dalam perusahaan ini menggunakan metode EOQ dalam penerapannya.

\section{Stock Opname}

Stock opname adalah kegiatan perhitungan fisik persediaan yang ada di gudang untuk kemudian dijual untuk mengetahui keakuratan catatan pembukuan yang merupakan salah satu fungsi sistem pengendalian intern. Dengan menggunakan stock opname akan diketahui stock persediaan dan mengetahui selisih antara keadaan fisik dengan catatan pembukuan persediaan barang. Dalam penelitian ini penulis membuat sistem untuk mengurangi kegiatan stock opname pada suatu perusahaan dagang, karena dengan adanya stock opname masih adanya kerawanan kecurangan dalam stock opname (Atmadja, dkk, 2013). 


\section{METODE PENELITIAN}

Penelitian pengembangan aplikasi AMIS merupakan penelitian deskriptif kualitatif, dengan sumber data yang digunakan adalah sumber data primer dan sekunder. Data primer dari penelitian ini adalah data yang diambil dari hasil observasi dan wawancara kepada responden dengan menggunakan metode random sampling (Saputra, 2018) dan data sekunder dari penelitian ini merupakan data-data yang terkait dengan penelitian terdahulu yang diambil dari studi literature berdasarkan referensi-referensi yang berhubungan dengan penelitian ini. Metode pengumpulan data yang digunakan ada tiga cara yaitu observasi langsung, wawancara dan studi literature.

Pengembangan model yang digunakan penelitian ini adalah model Traditional Systems Life Cycle. Model traditional systems life cycle merupakan metode untuk pembangunan system informasi, fase pendekatan pembangunan system, system pemisah pengembangan kedalam tahap formal. Tahap pengembangan system model traditional systems life cycle dapat diilustrasikan pada Gambar 1. 


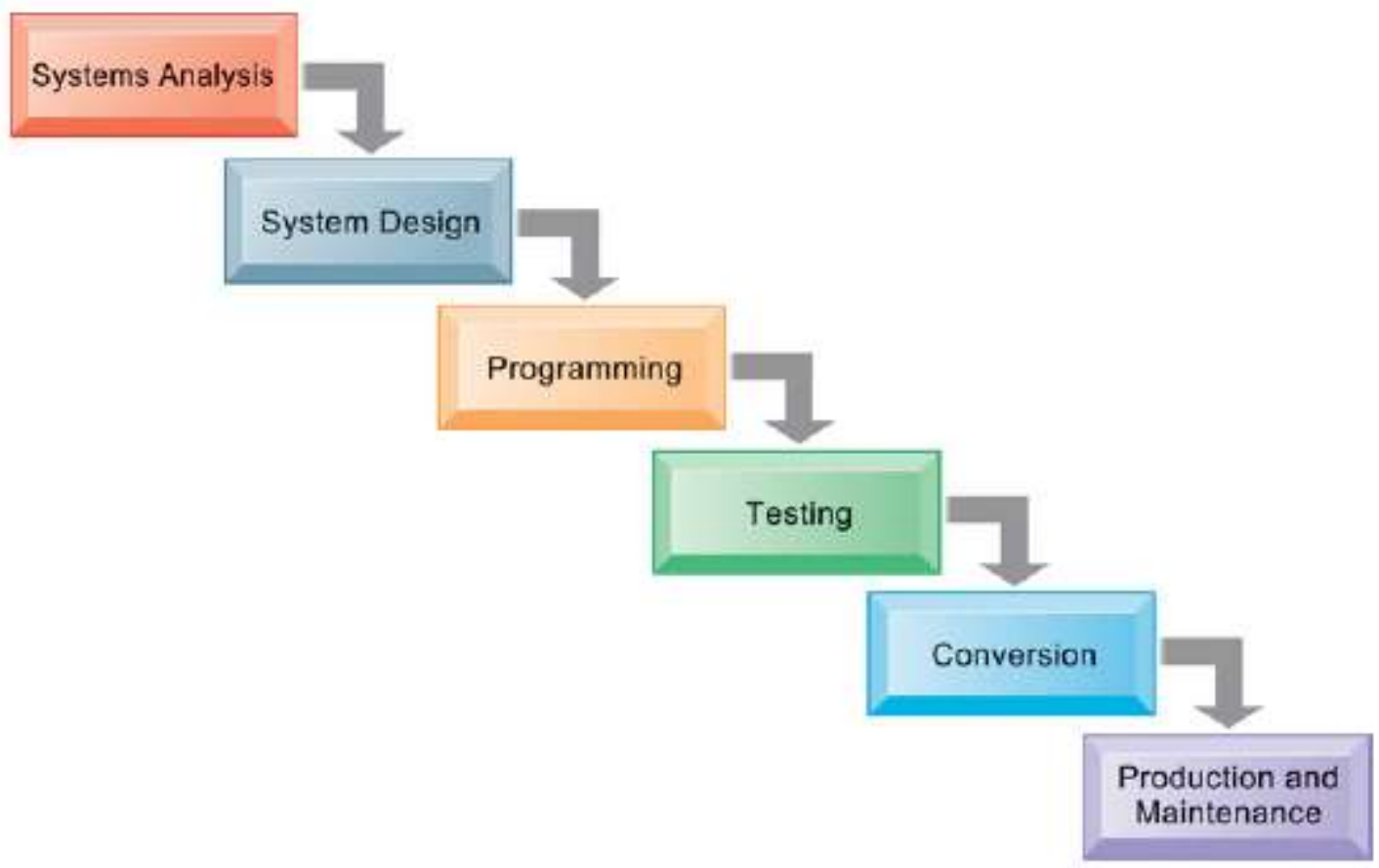

Gambar 1

Metode Traditional Systems Life Cycle

Sumber: Laudon Kenneth C. dan Jane P. Laudon: 553

1. System Analysis

Pada tahap ini merupakan proses analisis kebutuhan sistem. Pada analisis kebutuhan system dengan mengumpulkan data-data yang berkaitan tentang kebutuhan yang berkaitan dengan system yang akan dikembangakan. Data yang dibutuhkan seperti biaya yang terkait dari system yang akan dirancang, infrastruktur yang berhubungan dengan system, sumberdaya yang berhubungan dari system. 
2. System Design

Tahap ini melakukan proses multi langkah yang berfokus pada empat departemen, yaitu departemen penjualan, departemen pembelian, departemen persediaan dan manajemen persediaan. Proses analisis desain ini menerjemahkan hasil analisis kedalam perangkat lunak. Padatahap proses desain ini digambarkan sebuah diagram konteks yang menggambarkan hubungan system antar departemen yang berkaitan dengan system.

3. Programming

Pada tahap ini melakukan pembuatan perangkat lunak yang digunakan untuk system AMIS, dilakukan dengan cara memasukkan kode program akan bergantung pada hasil desain perangkat lunak pada tahap sebelumnya.

4. Testing

Setelah pengkodean, dilanjutkan dengan pengujian terhadap system yang telah dibuat. Pengujian dilakukan untuk mengetahui kesesuaian hasil output dari system dengan kebutuhan yang telah dirancang pada tahap analisis. 
5. Conversion

Pada tahap ini dilakukannya pengubahan dari system lama yang digunakan oleh suatu perusahaan dengan system yang telah dirancang ini yaitu AMIS.

6. Production and Maintenance

Dalam tahap ini dilakukannya proses penggunaan dari system. Dalam proses ini juga dilakukannya perbaikan dari system atau proses pembaharuan dari system AMIS.

\section{HASIL DAN PEMBAHASAN}

\section{Gambaran Umum dan Mekanisme Model Aplikasi Automatic}

\section{Management Inventory System}

AMIS (Automatic Management Inventory System) merupakan sebuah perangkat lunak yang berfungsi untuk membantu manajemen menyediakan laporan persediaan melalui sistem Economic Order Quantity (EOQ) berbasis aplikasi, sehingga dapat mengurangi potensi terjadinya kecurangan dan salah saji yang disebabkan kesalahan manusia.Pada umumnya perhitungan fisik persediaan yang ada di gudang dilakukan dengan cara manual atau yang biasa kita sebut dengan stock opname. AMIS dirancang sedemikian rupa 
untuk mengotomatisasi siklus persediaan dengan menggunakan metode EOQ. Hasil perhitungan EOQ merupakan input yang dimasukkan manajemen ke dalam aplikasi AMIS, kemudian diolah sedemikian rupa melalui beberapa proses dan melintasi beberapa bagian/departemen dalam perusahaan yang membutuhkan persediaan sebagai dasarnya. Sehingga pada akhirnya AMIS mampu memberikan output berupa beberapa laporan perdepartemen yang terkait dan laporan bulanan atas transakasi,

AMIS merupakan sebuah aplikasi yang membantu manajer dalam mengambil keputusan secara berkala melalui hasil laporan AMIS setiap bulan yang dianalisa berdasarkan aktifitas pembelian, penjualan dan penyimpanan persediaan. Peran manajer menjadi lebih mudah dan terotomatisasi dalam otorisasi, serta mengurangi missinformation antara bagian gudang, bagian pembelian dan bagian penjualan. Karena pada sistem AMIS, semua informasi tersedia, seperti yang digambarkan pada Gambar 2. Berikut ditampilkan sistem kerja AMIS secara umum: 


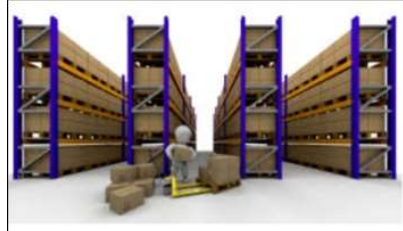

Bagian Gudang
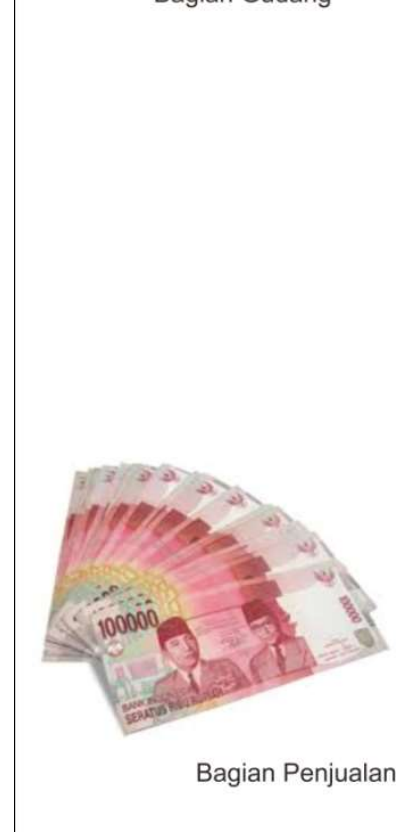

Bagian Penjualan
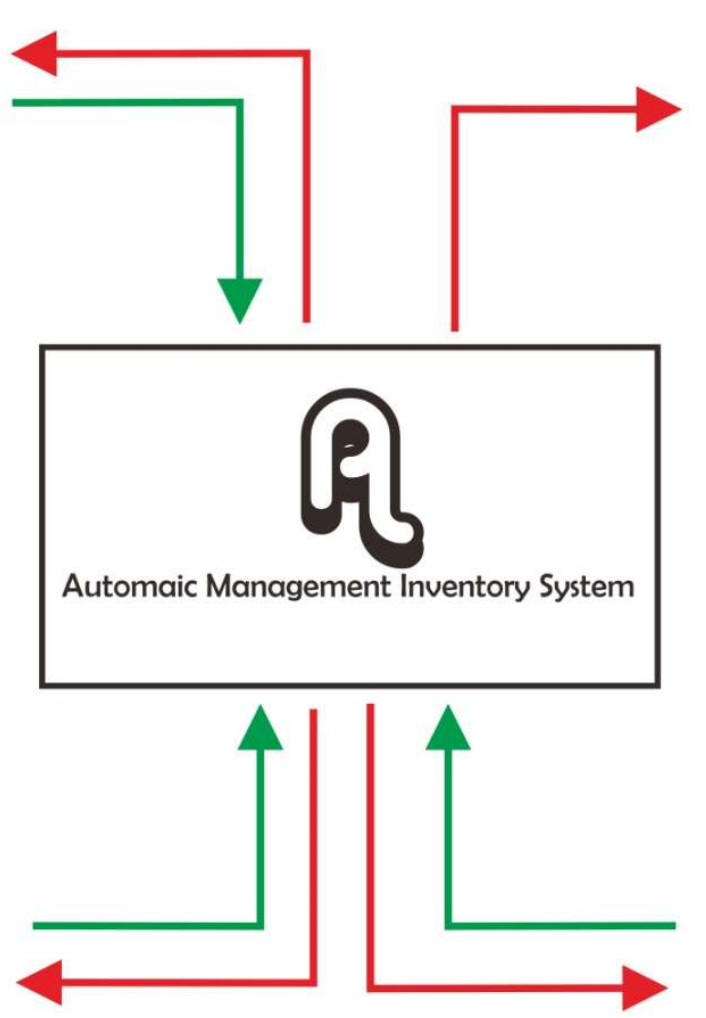

\section{PURCHASING}

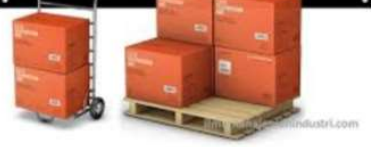

Bagian Pembelian

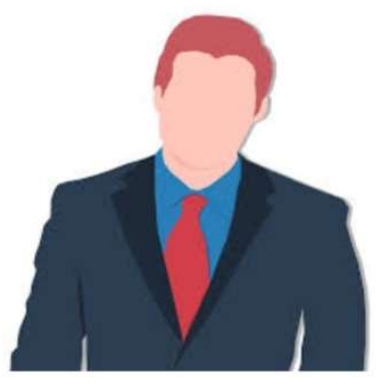

Manajer Persediaan

\section{Gambar 2}

DFD Level 0 tentang AMIS (Automatic Management Inventory System)

Sumber: Hasil Olahan, 2018

Bagian Gudang menginput list inventory yang meliputi kode barang, nama barang, harga barang dan tanggal pembelian barang, informasi ini dapat diketahui dari data perusahaan sebelum menggunakan AMIS. Manajer akan menginput rumus EOQ sesuai data yang diperoleh dari bagian gudang dan bagian pengeluaran (Biaya Penyimpanan dan Biaya Pemesanan). Ketika Bagian Penjualan akan menjual barang, terlebih dulu harus mengecek 
pesediaan melalui AMIS. Sementara, pada Bagian Pembelian akan melakukan pembelian ketika persediaan menunjukan EOQ, hal ini dapat ditunjukkan oleh notifikasi AMIS pada komputer bagian pembelian. Kemudian dokumen yang dikeluarkan oleh AMIS adalah purchase requisition. Semua transaksi di otorisasi oleh manajer, Setiap periode (per bulan, per semester, per tahun) AMIS akan mengeluarkan laporan bulanan atas transaski pembelian, penjualan dan penyimpanan persediaan.

\section{Cara Kerja dan Penggunaan Aplikasi Automatic Management Inventory System}

Cara kerja AMIS secara rinci dijelaskan dalam Data Flow Diagram Level 1 berikut : 


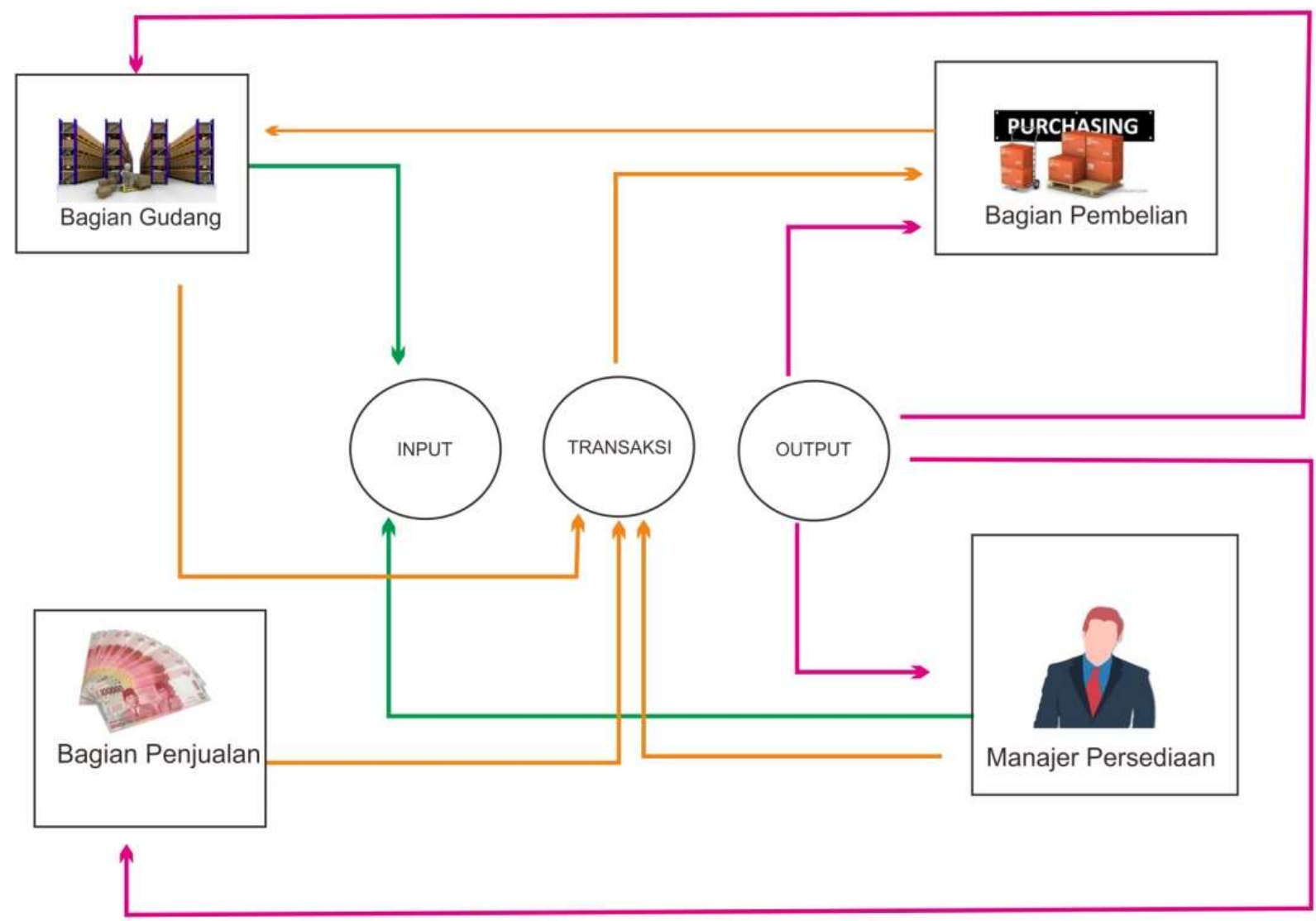

Keterangan

\section{Gambar 3}

DFD Level 1 tentang AMIS (Automatic Management Inventory System)

Sumber : Hasil Olahan, 2018

Dalam AMIS terdapat tiga bagian penting dalam memproses data, yaitu input, transaksi dan output. 
A. A. Gde Satia Utama dkk: Automatic Management Inventory System (AMIS) ...

Pada proses input, peran manajer persediaan menetapkan EOQ. Data yang dibutuhkan adalah daftar persediaan dan biaya biaya yang terkait dalam perhitungan EOQ, setelah proses input dilakukan maka sudah ditetapkan EOQ dari persediaan. AMIS menggunkan alat screening laser yang terpasang di gudang perusahaan, hal ini untuk menjaga keamanan barang keluar dan barang masuk di gudang. Sistem AMIS akan men-setting untuk notifikasi persediaan yang hampir mendekati EOQ agar bagian pembelian segera menyetok barang. Kemudian bagian penjualan meminta persediaan untuk memenuhi sales order dengan melihat stok persediaan di sistem AMIS, setelah barang terjual dan mendekati EOQ, maka proses selanjutnya pada proses transaksi.

Proses Transaksi pada perangkat lunak AMIS berisi tentang notifikasi perintah membuat dokumen purchase requisition kepada bagian pembelian melalui otorisasi manajer persediaan, setelah bagian pembelian membeli persediaan, maka bagian gudang akan menerima barang dan membuat laporan penerimaan barang. Kemudian diinput pada sistem AMIS, serta terpublish kepada semua pihak (manajer, bagian pembelian, bagian penjualan). Dari transasksi tersebut, Sistem AMIS secara otomatis akan mencocokan dokumen tentang pembelian dan dokumen penerimaan barang, apabila tidak sesuai maka laporan penerimaan barang tidak bisa diinput, 
akibatnya pembelian barang seolah-olah tidak terjadi meski ada dokumen permintaan barang, fungsi AMIS adalah untuk meminimalisir fraud yang terjadi di bagian gudang dan pembelian untuk penggelapan persediaan. Dengan demikian, manajer dapat mengetahui bahwa adanya permintaan pembelian yang belum diproses karena tidak sesuai dengan pesanan misalnya.

Pada akhir periode (sesuai kebutuhan pihak menajemen) pada proses output, AMIS akan mengeluarkan laporan persediaan yang terjadi selama periode berjalan. Sehingga pihak manajemen dapat mengetahui apakah bagian pembelian sudah melakuan pembelian sesuai AMIS. Pada bagian gudang terdapat screening laser yang berguna mengontrol persediaan masuk dan keluar sehingga output dari alat ini menjadi input program AMIS secara otomatis. 


\section{Kendala Pembuatan Sistem AMIS}

Tabel 1

Kendala Sistem AMIS

\begin{tabular}{|l|l|l|}
\hline $\begin{array}{l}\mathbf{N} \\
\mathbf{0}\end{array}$ & Kendala & Keterangan \\
\hline 1 & Biaya Mahal & $\begin{array}{l}\text { Biaya pertama kali (Initial Cost) yang } \\
\text { dikeluarkan adalah biaya pemrograman, } \\
\text { biaya setting awal untuk adabtasi } \\
\text { perusahaan, alat penunjang berupa } \\
\text { teknologi yaitu screening laser yang } \\
\text { dipasang di gudang, biay perawatan } \\
\text { hardware AMIS dan biaya pembaharuan } \\
\text { software AMIS. }\end{array}$ \\
\hline 2 & Sumber Daya Manusia & $\begin{array}{l}\text { Diperlukan Keahlian Khusus untuk } \\
\text { menangani resiko system } \\
\text { Kompetensi dibidang IT, Akuntansi, } \\
\text { Management, dan disiplin ilmu } \\
\text { lainnya } \\
\text { Keterbatasan } \\
\text { mempeajari sistem waktu }\end{array}$ \\
\hline 3 & Adaptasi System & $\begin{array}{l}\text { Adaptasi untuk perubahan sistem dari stok } \\
\text { opname manual kepada sistem AMIS yang } \\
\text { bersifat otomatis memerlukan penyesuaian } \\
\text { data-data lain di perusahaan }\end{array}$ \\
\hline 4 & Timelines & $\begin{array}{l}\text { Sosialisasi tidak cukup sekali } \\
\text { Pelatihan User beserta Trial error } \\
\text { system AMIS } \\
\text { Uji kelayakan memerlukan waktu } \\
\text { yang lama }\end{array}$ \\
\hline
\end{tabular}




\begin{tabular}{|l|l|l|}
\hline $\begin{array}{l}\text { N } \\
\mathbf{0}\end{array}$ & Kendala & Keterangan \\
\hline 5 & Infrastruktur & $\begin{array}{l}\text { Infrastruktur yang tersedia pada } \\
\text { perusahaan cukup terbatas, contohnya } \\
\text { dalam mendapatkan informas pemasok, } \\
\text { bagian pembelian perlu mengidentifikasi } \\
\text { dan memilih alternatif pembelian saat } \\
\text { dibutuhkan oleh sistem AMIS. }\end{array}$ \\
\hline
\end{tabular}

Sumber: Data diolah (2018)

\section{Resiko AMIS}

\section{Tabel 2}

\section{Resiko AMIS}

\begin{tabular}{|l|l|}
\hline No & Resiko \\
\hline 1 & $\begin{array}{l}\text { Identify Theft atau Pencurian identitas, merupakan sebuah kejahatan dimana } \\
\text { seorang penipu memperoleh sejumlah penting informasi personal, seperti } \\
\text { nomor ID manajer persediaan yang diketahui oleh karyawan, sehingga } \\
\text { pencuri dapat mengotorisasi pembelian dari notifikasi yang didapat oleh AMIS }\end{array}$ \\
\hline 2 & $\begin{array}{l}\text { Ketidakakuratan screen laser dalam mengidentifikasi persediaan di gudang, } \\
\text { dikarenakan menggunakan teknologi yang belum terbukti. }\end{array}$ \\
\hline 3 & Rentan terserang virus/malware yang mungkin menyerang sistem ini \\
\hline 4 & $\begin{array}{l}\text { Teknologi yang digunakan oleh sistem ini membutuhkan biaya yang tinggi } \\
\text { sehingga dapat mehambat perancangan sistem ini }\end{array}$ \\
\hline
\end{tabular}

Sumber: pengolahan data kualitatif (2018) 


\section{Biaya Perancangan AMIS}

Sebelum Menggunakan AMIS

\section{Tabel 3}

\section{Biaya Perancangan AMIS}

\begin{tabular}{|c|c|c|c|c|c|}
\hline & & \multicolumn{2}{|c|}{ Biaya Satuan } & \multicolumn{2}{|c|}{ Total Biaya } \\
\hline $\begin{array}{lcc}\text { Biaya } & \text { Tenaga } & \text { Kerja } \\
\text { bagian } & \text { Perhitungan } \\
\text { Persediaan } & & \\
\end{array}$ & 100 Orang & $\mathrm{Rp}$ & 50.000 & $\mathrm{Rp}$ & 5.000 .000 \\
\hline $\begin{array}{l}\text { Biaya Tenaga Kerja } \\
\text { Bagian Input Persediaan }\end{array}$ & 10 Orang & $\mathrm{Rp}$ & 100.000 & $\mathrm{Rp}$ & 1.000 .000 \\
\hline $\begin{array}{ll}\text { Biaya Tenaga } & \text { Kerja } \\
\text { Pengantar } & \text { Laporan } \\
\text { (Kurir) (6bulan) } & \\
\end{array}$ & 5 Orang/bln & $\mathrm{Rp}$ & 3.000 .000 & $\mathrm{Rp}$ & 36.000 .000 \\
\hline $\begin{array}{ll}\text { Biaya } \\
\text { (6bulan) }\end{array}$ & - & $\mathrm{Rp}$ & 5.000 .000 & $\mathrm{Rp}$ & 30.000 .000 \\
\hline Total Biaya Per 6 Bulan & & & & $\mathrm{Rp}$ & 42.000 .000 \\
\hline
\end{tabular}

Sumber: studi dokumentasi (2018)

Setelah Menggunakan AMIS

Tabel 4

\section{Biaya implementasi AMIS}

\begin{tabular}{|c|c|c|c|c|}
\hline & & Biay & Satuan & Total Biaya \\
\hline $\begin{array}{c}\text { Biaya Hardware (Awal) } \\
-\quad \text { Komputer } \\
-\quad \text { Screening Laser }\end{array}$ & $\begin{array}{l}5 \text { Unit } \\
1 \text { Unit }\end{array}$ & $\begin{array}{l}\mathrm{Rp} \\
\mathrm{Rp}\end{array}$ & $\begin{array}{l}5.000 .000 \\
100.000 .000\end{array}$ & $\begin{array}{lr}\text { Rp } & 25.000 .000 \\
R p & 100.000 .000\end{array}$ \\
\hline Biaya Software (Awal) & & $\mathrm{Rp}$ & 5.000 .000 & 5.000 .000 \\
\hline $\begin{array}{ll}\text { Biaya } & \text { Maintanance } \\
\text { (Bulanan) } & \end{array}$ & 1 Unit/bulan & $\mathrm{Rp}$ & 1.000 .000 & 6.000 .000 \\
\hline Biaya Pelatihan (Awal) & 3x Pelatihan & $\mathrm{Rp}$ & 1.500 .000 & $\begin{array}{ll}\mathrm{Rp} & 4.500 .000 \\
\end{array}$ \\
\hline \multicolumn{4}{|l|}{ Total Biaya } & Rp140.000.000 \\
\hline
\end{tabular}

Sumber: Studi dokumentasi (2018) 
Sebelum menggunakan AMIS

Biaya sebesar Rp 42.000.000 dikeluarkan perusahaan setiap kali melakukan stock opname. Dan biaya-biaya yang dikeluarkan per bulan, yang apabila menggunakan AMIS biaya tersebut bisa diminimalisir bahkan dihilangkan. Seperti biaya kurir dan biaya administrasi. Biaya stock opname pun semakin lama diprediksi akan terus meningkat, mengingat honor/upah tenaga kerja manusia yang akan terus meningkat.

Setelah menggunakan AMIS

Biaya sebesar Rp 140.000.000 yang dikeluarkan perusahaan hanya pada awalnya saja. Namun pada akhirnya biaya tersebut rendah dan stabil. Berikut perbedaan yang signifikan dari biaya setelah menggunakan AMIS dan sebelum menggunakan AMIS. Perbedaan sangat signifikan tampak pada tahun ke-3 dan seterusnya setelah biaya tenaga kerja manusia diestimasi meningkat Rp 25.000 perorang, dan biaya lainnya meningkat juga.

Tabel 5

\section{Perbandingan sebelum dan sesudah AMIS}

\begin{tabular}{|l|lr|lr|}
\hline & \multicolumn{2}{|l|}{ Sebelum Menggunakan AMIS } & \multicolumn{2}{l|}{ Setelah Menggunakan AMIS } \\
\hline Tahun Ke-1 & $\mathrm{Rp}$ & 82.000 .000 & $\mathrm{Rp}$ & 280.000 .000 \\
\hline Tahun Ke-2 & $\mathrm{Rp}$ & 82.000 .000 & $\mathrm{Rp}$ & 12.000 .000 \\
\hline Tahun Ke-3 & $\mathrm{Rp}$ & 102.500 .000 & $\mathrm{Rp}$ & 12.000 .000 \\
\hline Tahun Ke-4 & $\mathrm{Rp}$ & 102.500 .000 & $\mathrm{Rp}$ & 18.000 .000 \\
\hline Tahun Ke-5 & $\mathrm{Rp}$ & 102.500 .000 & $\mathrm{Rp}$ & 18.000 .000 \\
\hline & $\mathrm{Rp}$ & 471.500 .000 & $\mathrm{Rp}$ & 340.000 .000 \\
\hline
\end{tabular}

Sumber: Studi dokumentasi (2018) 


\section{KESIMPULAN}

AMIS mempunyai tiga proses pokok, yaitu input, transaksi dan output. Pada proses input, dilakukan setting awal mengenai EOQ dan semua informasi perediaan. Pada proses transaksi, AMIS secara otomatis memberitahukan bahwa diperlukannya pembelian persediaan barang kepada bagian pembelian, manajer persediaan, bagian gudang, dan bagian penjualan. Pada proses output, AMIS mengeluarkan laporan periodik mengenai siklus persediaan yang terjadi selama periode berjalan. AMIS menggunakan screening laser untuk membantu mengolah data persediaan serta menjaga keamanan persediaan di gudang. Kendala dalam pembuatan AMIS adalah biaya yang mahal, sumber daya manusia yang harus mempunyai standard kinerja, adaptasi sistem sulit, timelines dalam pembuatan program yang lama dan infrastruktur yang kurang memadai dalam penyampaian informasi. Resiko AMIS yang sangat rentan adalah adanya pencurian identitas, ketidakakuratan screening laser, terserangnya virus/malware, dan hambatan biaya. AMIS dapat menghemat pengeluaran dan beban perusahaan pada jangka panjang. Penelitian selanjutnya dapat melakukan riset dengan studi kuantitatif di berbagai perusahan, sehingg 
dapat menyentuh berbagai macam jenis perusahaan yang menggunakan AMIS.

\section{Daftar Pustaka}

Admin. (2018). Pengertian Manajemen Persediaan, Jenis dan Tujuannya. Rocket Manajemen. $\quad$ Diakseks $10 \quad$ Mei 2018. http://rocketmanajemen.com/manajemen-persediaan/.

Andini, Wienda Velly dan Achmad Slamet. (2016). Analisis Optimasi Persediaan Bahan Baku Dengan Menggunakan Metode Economic Order Quantity pada CV. Tenun/ATBM Rimatex Kabupaten Pemalang. Management Analysis Journal 5 (2): 143-148.

Atmadja, A. T., \& Saputra, K. A. K. (2018). Determinant Factors Influencing the Accountability of Village Financial Management. Academy of Strategic Management Journal. Vol. 17. Issue 1.

Atmadja, Anantawikrama T., Komang Adi Kurniawan Saputra., dan Diota P.V. (2013). Akuntansi Manajemen Sektor Publik. Undiksha Press.

Ibraraharie, Mahardhita nanda . (2016) . Mengungkap Kecurangan Pencatatan Persediaan Barang Studi Kasus Pada PT Agung Aquatic Marine . Surabaya : Jurnal Ilmu dan Riset Akuntansi . 
A. A. Gde Satia Utama dkk: Automatic Management Inventory System (AMIS) ...

Kho, Budi. (2016). Pengertian Manajemen Persediaan (Management Inventory). Ilmu Manajemen Industri. Diakses 10 Mei 2018. https://ilmumanajemenindustri.com/pengertian-manajemen-persediaaninventory-management-2/.

LLC.(2018).Investopedia.https://www.investopedia.com/terms/e/economicord erquantity.asp

Murtanto. (2013). Sistem Pengendalian Internal. Jakarta : Mitra Utama.

Sari, Resa Febrian . (2014) .Evaluasi Sistem Pengendalian Intern atas Persediaan CV Erlangga . Sidoarjo :Artikel Mahasiswa 2014 .

Amelia dan Joni Devitra. (2018). Analisis dan Perancangan Sistem Informasi Manajemen Persediaan Barang pada Advan Service Center Jambi. Jurnal Manajemen Sistem Informasi. Vol 3 (1): 856-869.

Saputra, Komang Adi Kurniawan., L.G.P. Sri Ekajayanti, dan Putu Budi Anggiriawan. (2018). Kompetensi Sumber Daya Manusia dan Sikap Love of Money dalam Pengelolaan Keuangan Usaha Mikro Kecil dan Menengah. Jurnal Reviu Akuntansi dan Keuangan, Vol. 8, No. 1.

Sugiyono. (2009). Metode Penelitian Bisnis. Alfabeta, Bandung.

Tuerah, Michael Chandra. (2014). AnalisisPengendalianPersediaanBahan Baku Ikan Tuna pada CV. Golden KK. Jurnal EMBA Vol. 2 (4): 524-536. 
Warni, Sri. (2016). Apa Itu Stock Opname dan Kapan Ia Seharusnya Dilakukan?. Zahir Blog[Internet].https://zahiraccounting.com/id/blog/ apa-itu-stock-opname-dan-kapan-ia-seharusnya-dilakukan/.

Yosan, R. Bagus, Muhammad Kholil, Bhetriza Hanum. (2018). Implementation of Inventory Management System (IMS) Case Study on XYZ Online Store Business Unt. IOP Conf. Series: Materials Science and Engineering. 343: 1-9.

Laudon, Kennet C dan Jane P. Laudon. (2016). "Management Information Systems". Pearson Education Limited 